\title{
Analisis Praktik Arisan Barang Di Desa Wawonduru Kecamatan Woja Kabupatten Dompu Dalam Perspektif Ekonomi Islam
}

\author{
Rizky Amelia ${ }^{1 *}$, Ainun Mulyani ${ }^{2}$ \\ 1,2) Institut Agama Islam Muhammadiyah Bima \\ ${ }^{*}$ Corresponding Author: rizkyameliakiki40@yahoo.com
}

\begin{abstract}
ABSTRAK -Penelitian ini bertujuan untuk mengetahui bagaimana praktik arisan barang di Desa Wawonduru. Penelitian menggunakan pendekatan kualitatif dengan subjek penelitian adalah ketuaketua arisan barang dan anggota-anggota arisan barang yang ada di Desa Wawonduru. Dan objeknya adalah praktik arisan barang di Desa Wawonduru. Data penelitian dihimpun melalui metode observasi, wawancara dan dokumentasi. Berdasarkan hasil penelitian, dapat disimpulkan bahwa praktik arisan barang di Desa Wawonduru lahir disebabkan karena ketidakmampuan masyarakat untuk membeli barang secara tunai, para ketua dan anggota arisan menggunakan akad lisan dalam praktik arisannya, dalam penentuan nomor urut arisan terdapat ketidakadilan dan hal tersebut dilarang dalam Islam. Pengambilan keutungan yang dilakukan oleh ketua-ketua arisan merupakan hal yang dilarang dalam Islam karena pada dasarnya arisan seharusnya dilakukan untuk saling tolong menolong antar sesama, dan terdapat unsur penipuan terhadap kualitas barang arisan. Namun pada praktik arisan barang di Desa Wawonduru ini terdapat unsur kemaslahatan bagi ketua dan anggota-anggota arisan karena banyak yang merasa terbantu dengan adanya praktik arisan barang tersebut.
\end{abstract}

Kata Kunci - Arisan; Barang; Perspektif Ekonomi Islam

\section{PENDAHULUAN}

Manusia adalah makhluk sosial yaitu makhluk yang selalu membutuhkan keberadaan orang lain. Dalam pemenuhan kebutuhannya, manusia harus tolong menolong dan bekerja sama. Hal ini disebabkan karena pada suatu saat seseorang memiliki sesuatu yang dibutuhkan orang lain, sedangkan orang lain membutuhkan sesuatu yang dimiliki seseorang tersebut, sehingga terjadilah hubungan saling memberi dan menerima. ${ }^{1}$

Menurut Farley, perubahan sosial merupakan perubahan pola perilaku, hubungan sosial, lembaga, dan struktur sosial pada waktu tertentu. Ini menunjukan bahwa dalam masyarakat terjadi perubahan interaksi antara yang satu dengan yang lain ketika mereka melakukan tindakan dan kegiatan. Adam Smith juga mengatakan bahwa, perubahan akan terjadi berkaitan dengan perekonomian masyarakat yang mengalami pergantian. ${ }^{2}$

Sebagaimana realita yang terjadi sekarang, bahwa perubahan pola ekonomi/transaksi ekonomi ditengah masyarakat. Jika dulu kebutuhan

1 Surya Darma Putra, "Pemikiran Ibnu Taimiyah Tentang Standar Harga Dalam Jual Beli", dalam www. repository.uin-suska.ac.id., diambil taggal 5 februari 2021, pukul 09:00 Wita.

2 Irwan dan Indraddin, Strategi dan Perubahan Sosial, (Yogyakarta: Deepublish, 2016), 2. 
ekonomi dapat dilakukan dengan pembelian barang secara langsung atau tidak langsung, maka masa kini, pembelian barang dapat dilakukan melalui sistem arisan. Dimana kehidupan sosial dalam transaksi ekonomi mulai berubah, yang tadinya dalam pembelian barang itu harus melakukan transaksi langsung dengan penjual barang, namun masa kini tidak lagi, karna perubahan transaksi ekonomi, pemenuhan kebutuhanpun bisa melalui sistem arisan.

Arisan merupakan kegiatan mengumpulkan uang atau barang yang bernilai sama oleh beberapa orang kemudian diundi diantara mereka yang menentukan siapa yang memperolehnya, undian dilaksanakan pada sebuah pertemuan secara berkala sampai semua anggota memperolehnya. Periode putaran arisan berakhir apabila semua anggota arisan telah memenangkan undian. ${ }^{3}$

Ratih Ibrahim, Psikolog Lulusan Universitas Indonesia, pendiri Personal Growth, wadah layanan psikolog untuk masyarakat mengatakan, untuk kebanyakan orang, arisan adalah kegiatan menyenangkan. Pasalnya, kebutuhan kumpul-kumpul terpenuhi dengan bertemu teman-teman. Ajang ini juga dianggap ampuh untuk pelepasan stress, akibat menumpuknya pekerjaan kantor atau masalah rumah sehingga beban di bahu plong. Selain itu, arisan juga membuat aktivitas menabung menjadi tidak terasa, karena bila beruntung bisa langsung mendapat uang dalam jumlah besar. ${ }^{4}$ Tujuan dari penelitin ini Untuk Mengetahui bagaimana praktik arisan barang di Desa Wawonduru dalam perspektif ekonomi Islam dan bagaimana pandangan islam terhadap praktik arisan barang.

\section{TINJAUAN PUSTAKA}

Berbagai penelitian mengenai praktik arisan barang dalam islam telah banyak diteliti sebelumnya. Jurnal penelitian yang membahas kemiripan teori maupun subjek penelitian dijadikan acuan dalam penelitian ini. Berikut merupakan penelitian terdahulu yang membahas mengenai arisan barang:

Hasil Penelitian Acing Olana yang berjudul "Praktik Jual Beli Dengan Sistem Arisan (Studi Kasus Akun Facebook Risa Nadef)" dalam penelitan ini secara rinci menjelaskan tentang hukum jual beli dengan sistem arisan, yang pada dasarnya adalah halal dan boleh, hal itu sesuai dengan hukum dasar transaksi dan muamalah, karna kalau dilihat pada sistem subtansinya arisan merupakan akad

${ }^{3}$ Irma Prihantari, Tinjaun Hukum Islam Terhadap Praktik Arisan Sepeda Motor Paguyuban Agung Rezeki Dikecamatan Sentolo Kabupaten Progo, dalam www.digilib.uin-suka.ac.id., diambil tanggal 5 februari 2021, 09:10 Wita.

4 Joy Roesma, Nadia Mulya, Kocok,Uncut-The Untold Stories Of Arisan Ladies And Sosiatites, (Jakarta: Pt Gramedia, 2013), 46. 
utang piutang yang diperbolehkan dalam islam. ${ }^{5}$ Persamaan penelitian di atas dengan peneliti ini, yaitu sama-sama menggunakan sistem arisan untuk transaksi ekonomi yang dilakukan dengan secara berangsur-angsur sesuai dengan ketetapan waktu yang telah disepakati secara berasama oleh pihak yang bersangkutan. Sedangkan perbedaan penelitian yang dilakukan oleh Acing Olana dan peneliti ini adalah, terletak pada objeknya, acing olana menjadikan akun facebook risa nadef sebagai objeknya, sedangkan objek peneliti ini yaitu langsung ketua-ketua, dan anggota-anggota kelompok arisan yang ada di Desa Wawonduru.

Hasil Penelitian Ervani Muslimah, yang berjudul "Sistem Arisan Perabot Rumah Tangga Perspektif Etika Bisnis Islam di Desa Raman Aji Kecamatan Raman Utara Lampung Utara" dalam penelitian ini, peneliti menggambarkan secara konperhensif mengenai faktor-fator yang memperngarauhi masyarakat untuk ikut berkecimpung dalam kelompok arisan perabot rumah tangga. ${ }^{6}$ Perbedaan penelitian yang dilakukan oleh Erviani Muslimah dengan peneliti ini yaitu, peneliti ini lebih memfokuskan pembahasannya kepada praktik arisan barang di Desa Wawonduru dalam perspektif ekonomi Islam, sedangkan Ervani Muslimah lebih memfokuskan pada faktor-faktor pendorong masyarakat untuk ikut kelompok arisan perabot rumah tangga. Sedangkan persamaanya yaitu, sama-sama menggunakan sistem arisan barang dalam melakukan penelitan.

Hasil Penelitian Toto Erwandi, yang berjudul "Praktik Arisan Barang Dalam Kajian Hukum ekonomi Syariah (Studi di Desa Sebangau Permai Kecamatan Sebangau Kuala kabupaten Pulang Pisau)" dalam penelitian ini, peneliti menggambarkan tentang praktik arisan barang yang ada di Desa Sebangau dan mengkorelasikannya dengan akad-akad yang berelevansi dengan arisan, yang pada hukumnya arisan diperbolehkan, kembali pada "hukum muamalah yaitu segala sesuatu diperbolehkan kecuali ada dalail yang mengharamkannya". Persamaan penelitian yang dilakukan oleh Toto Erwandi dengan peneliti ini yaitu sama-sama menjadikan praktik arisan barang dalam Islam sebagai objek pembahasan dan desa sebagai tempat penelitian. Perbedaan penelitian yang dilakukan oleh Toto Erwandi dengan peneliti ini yaitu pada masalah yang diangkat, Toto Erwandi memfokuskan pada pratik arisan barang dengan berbagai pertimbangan yaitu menggunakan teori kepastian hukum, keadilan, akad, maslahah, dan urf. Sedangkan peneliti ini hanya mengangkat masalah praktik arisan barang dan hukumnya. ${ }^{7}$

\footnotetext{
${ }^{5}$ Acing Olana, "Praktik Jual Beli Dengan Sistim Arisan (Study Kasus Akun Facebook Rica Nadef)", dalam www.repository.iain-metro.ac.id.,diambil tanggal 6 maret 2021, pukul 14:30 wita.

6 Erviana Muslimah, "Sistem Arisan Perabot Rumah Tangga Perspektif Etika Bisnis Islam di Desaraman Aji Paomacan Kecamatan Sukamaju Kabupaten Luwu Utara Lampung Timur", dalam www.repository-iain-metro.ac.id. diambil pada tanggal 20 februari 2021, pukul 15:00 wita.

7Toto Erwandi, Praktik Arisan Barang Dalam Kajian Hukum ekonomi Syariah (Studi di Desa Sebangau Permai Kecamatan Sebangau Kuala kabupaten Pulang Pisau), dalam www.repository-iainpalangkaraya.ic,id.,diambil tanggal 22 februari 2021, pukul 19:10 wita.
} 


\section{METODOLOGI PENELITIAN}

Jenis penelitian yang digunakan oleh peneliti adalah kualitatif deskriptif dan eksploratif, deskriptif artinya menggambarkan kondisi apa adanya, tanpa memanipulasi variabel yang akan diteliti. Sedangkan eksploratif adalah memahami gejala sentral, untuk memahami gejala sentral tersebut peneliti mewawancarai peserta penelitian untuk mengajukan pertanyaan umum dan agak luas. Informasi yang disampaikan akan dikumpulkan, informasi tersebut biasanya berupa kata atau teks. ${ }^{8}$ Peneliti menggunakan cara berfikir induktif untuk menganalisis data yaitu pengambilan kesimpulan dimulai dari pernyataan atau fakta-fakta khusus menuju kesimpulan yang bersifat umum. ${ }^{9}$ Sehingga dalam penelitian ini setelah semua data seperti hasil observasi, wawancara dan dokumentasi diperoleh, maka akan dianalisis data tentang Praktik Arisan Barang Di Desa Wawonduru Kab.Dompu Dalam Perspektif Ekonomi Islam.

\section{PEMBAHASAN}

\section{Pengertian Arisan}

Abdul Bashith dalam bukunya Islam dan Manajemen Koperasi, arisan adalah bentuk kerjasama dengan menyerahkan sejumlah uang tertentu kemudian diundi untuk memutuskan siapa yang dapat menerimanya. Pada waktu berikutnya yang telah disepakati, mekanisme itu diulang lagi dan yang telah memperoleh pada kesempatan sebelumnya tetap harus menyetorkan sejumlah uang dan ia tidak dapat lagi menarik dana. Demikian seterusnya sampai semua anggota mendapatkan giliran. ${ }^{10}$

Martowijoyo mendefinisikan arisan sebagai rotating savings and credit assosiation (ROSCA) atau asosiasi tabungan dan kredit bergilir. Arisan adalah bentuk keuangan mikro. Varadharajan (2004) menjelaskan bahwa ROSCA atau arisan merupakan perkumpulan sosial yang berlangsung dalam interval waktu yang tetap, dengan lokasi perkumpulan biasanya. diselenggarakan dirumah masing-masing anggota arisan secara bergiliran. ${ }^{11}$

Arisan adalah alternatif daripada berutang pada bank atau bentuk kredit yang lain. Secara umum, tidak ada tarikan bunga pada sistim arisan. Dalam

${ }^{8}$ Conny R. Semiawan, Metode Penelitian Kualitatif, ( Cikarang: Gramedia Widiasarana Indonesia: 2010), 7.

${ }^{9}$ Nana Sudjana, Tuntunan Penyusunan Karya Ilmiah,(Bandung: Sinar Baru Algosindo, 2011), 7.

${ }^{10}$ M.Rohman Rozikin, Hukum Arisan Dalam Islam Kajian Figh Terhadap Praktik Rosca (Rotating Savings And Credit Asosiation), (Malang : Ub Press, 2018), 25.

11 Rozikin, Hukum Arisan... 
sejumlah kasus, arisan tidak menonjol unsur sosialnya tetapi hanya mencerminkan sirkulasi uang diantara para anggota. ${ }^{12}$

\section{Praktik Arisan Barang Di Desa Wawonduru Kab.Dompu}

1. Cara Melakukan Akad Praktik Arisan Barang

Berdasarkan pernyataan yang disampaikan oleh ketua dan anggota arisan yang ada di Desa Wawonduru bahwa akad mengenai kondisi barang dibuat kemudian disepakati oleh anggota arisan yang dilakukan di awal, sebelum arisan dimulai, termaksud akad mengenai kondisi barang yang apabila tidak sesuai dengan apa yang dijanjikan maka akan dikembalikan.

Didalam Al-Qurean ada istilah yang menghubungkan dengan perjanjian, yaitu al-aqdu (akad) dan al-ahdu (janji). Pengertian akad secara bahasa ikatan, mengikat. Dalam kata al-aqdu yang terdapat dalam surah AlMaidah ayat 1 . Suatu pernyataan dan seseorang untuk mengerjakan atau tidak untuk mengerjakan sesuatu yang tidak berkaitan dengan orang lain. Istilah tersebuat terdapat dalam surah Ali Imran ayat 76.

Terjemahan :(Bukan demikian), sebenarnya siapa yang menepati janji (yang dibuat)nya dan bertakwa, Maka Sesungguhnya Allah menyukai orang-orang yang bertakwa.(QS. Ali-Imran:76)13

Abu Ja'far menjelaskan didalam tafsir Ath Thabari berita tentang orang yang menunaikan amanat kepada orang yang berhak mendapatkannya, semata-mata karena ketakwaannya kepada Allah. Maknanya Allah berfirman" Sebenarnya barang siapa yang menjanjikan kepada Allah, yang telah mereka ikat dalam Al-Kitab, lalu beriman kepada Muhammad dan membenarkan segala perkara yang dibawanya, menunaikan amanat kepada yang berhak, juga taat kepada perintah dan larangan Allah yang lainnya. Meskipun akad dalam praktik arisan barang ini secara lisan, tetapi ia akan terus menerus mengikat para pihak, dimana akad mengandung asas janji artinya mengikat kedua belah pihak dan wajib memenuhi. 14

Berdasarkan penjelasan diatas tentang akad bahwa tidak adanya larang dalam Islam meskipun akad yang dilakukan secara lisan saja. Sebagaimana Allah menjelaskan dalam surah Ali Imran ayat 76 diatas

$12 \mathrm{Ibid}, .12$.

${ }^{13}$ Qs. Al-Imran (3): 76.

14 Abu Ja"far Muhammad, Penerjemah Beni Sarbeni, Tafsir Ath-thabari, (Jakarta: Pustaka Azzam, 2008),501. 
menunaikan amanat kepada yang berhak. Artinya adanya sebuah kewajiban antar kedua belah pihak bila melakukan akad atau perjanjian.

2. Cara Mengundi Nomor Urut Arisan Barang

Ibu Ayu mengatakan bahwa praktik arisan barang di Desa Wawonduru di laksanakan pada setiap bulan. Mereka melakukan pemilihan nomor atau menentukan undian secara keseluruhan terlebih dahulu untuk menentukan pengambilan barang pada bulan-bulan selanjutnya, misalnya 10 orang, maka keseluruhannya diundi. Namun, dalam arisan ini, pengelola pada urutan pertama sesuai dengan hasil kesepakatan bersama, sedangkan anggota yang lainnya tergantung sistem undi, namun ada juga para anggota yang minta bertukaran nomor undian dengan ketua arisan, sehingga mereka bisa menjadi pemenang pertama. ${ }^{15}$

Jika dihubungkan dengan keadilan, keadilan dalam Islam yaitu mengatur semua segi kehidupan manusia secara seimbang dan menyeluruh. ${ }^{16} \mathrm{Hal}$ ini Islam mempunyai konsep menyeluruh dan lengkap tentang alam dan manusia. Islam tidak mengklasifikasi tentang derajat manusia satu dengan yang lainnya, semuanya sama dihadapan Tuhan, yang membedakan adalah ketakwaan hamba-Nya. Sebagaimana Allah menjelaskan dalam firmanya surah An-Nahl ayat 90.

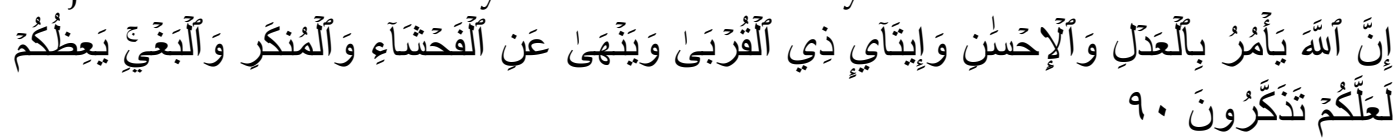

Terjemahan: Sesungguhnya Allah menyuruh (kamu) berlaku adil dan berbuat kebajikan, memberi kepada kaum kerabat, dan Allah melarang dari perbuatan keji, kemungkaran dan permusuhan. Dia memberi pengajaran kepadamu agar kamu dapat mengambil pelajaran. ${ }^{17}$

Berdasarkan ayat di atas dalam penafsiran M. Quraish Shihab dihubungkan dengan praktik penentuan nomor urut undian arisan barang yang dilakukan secara undi habis dan ketua pada urutan pertama ataupun terakhir tanpa diundi. Dari praktik tersebut maka timbullah ketidak sesuaian yang dimana ketua arisan ditentukan waktunya untuk menjadi pemenang, sedangkan anggota-anggota arisan harus melalui pengundian terlebih dahulu.

Menurut Han Rawls, keadilan merupakan nilai yang mewujudkan keseimbangan antara bagian-bagaian dalam kesatuan, antara tujuan-tujuan

\footnotetext{
15 Ayu Anggrini, Wawancara, Dompu, 11 Juli 2021.

${ }^{16}$ M. Yatimin Abdulla, Pengantar Studi Etika, (Jakarta: PT. Raja Grafindo Persada, 2006), 538.

17 (Qs.An.Nahl (16): 90).
} 
pribadi dan tujuan bersama. Dalam konteks tersebut mengandung dua makna. Adapun makna tersebut antara lain:

a. Prinsip kesamaan, pada dasarnya menuntut adanya pembagian secara merata dan proposional.

b. Prinsip ketidaksamaan, situasi ketidaksamaan harus diberikan aturan sedemikian rupa sehingga menguntungkan golongan masyrakat yang paling lemah. ${ }^{18}$

Dari beberapa pengertian di atas bahwa, keadilan semua hal yang berkenaan dengan sikap dan tindakan dalam hubungan antar manusia, keadilan berisi sebuah tuntutan agar orang memperlakukan sesamanya sesuai dengan hak dan kewajibannya, perlakuan tersebut tidak pandang bulu atau pilih kasih; melainkan, semua orang diperlakukan sama sesuai dengan hak dan kewajibannya. ${ }^{19}$ Islam sendiri memberikan konsep keadilan yang memadai. Al-Qurean membicarakan keadilan dalam berbagai konteks. Kata adil disebutkan sebanyak 28 kali, kata AlQistsebanyak 25 kali, baik dalam bentuk kata kerja (fi'il) maupun kata benda (isim) kemudian kata Al-Wazndisebutkan sebanyak 20 kali dalam bentuk kata kerja (fi'il) maupun kata benda (isim). ${ }^{20}$

Ada ayat Al-Qurean yang memerintahkan manusia untuk berlaku adil dalam Surah An-Nisa ayat 58.

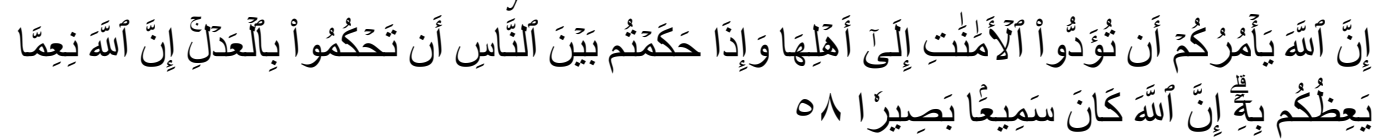

Terjemahan: Sesungguhnya Allah menyuruh kamu menyampaikan amanat kepada yang berhak menerimanya, dan (menyuruh kamu) apabila menetapkan hukum di antara manusia supaya kamu menetapkan dengan adil. Sesungguhnya Allah memberi pengajaran yang sebaikbaiknya kepadamu. Sesungguhnya Allah adalah Maha Mendengar lagi Maha Melihat. ${ }^{21}$

Ayat-ayat Al-Quran cukup banyak yang berkaitan dengan keadilan. Banyaknya ayat-ayat tersebut memberikan pemahaman bahwa pentingnya untuk berlaku adil terhadap sesama. Artinya keadilan itu diperlakukan untuk ketentraman dalam kebersamaan.

18 Titik Triwulan Tutik, Pengantar Ilmu Hukum, (Jakarta: Prestasi Pustaka, 2006), 227.

19 Uis Amalia, Keadilan Distributif Dalam Ekonomi Islam, (Jakarta, Raja Grafindo Persada, 2009),115116.

20 Agus Romdlon S, Konsep Keadilan Menurut Al-Qur"eAn Dan Para Filosof, Jurnal Dialogia, Ponorogo: STAIN Ponorogo, No.2/ Vol. 10/ 2012, 186.

${ }^{21}$ Qs.An-Nisa Ayat (4) 58. 
Menurut hemat peneliti jika praktik arisan dalam penentuan nomor urut arisan hanya diperuntukkan kepada anggota dan pengelola tidak, maka hal itu tidak adanya keseimbangan, kecuali hal tersebut telah disepakati oleh seluruh anggota. Islam tidak mengklasifikasi tentang derajat manusia satu dengan yang lainnya, semuanya sama dihadapan tuhan, yang membedakan adalah ketakwaan hamba-nya. Maka dalam hal penentuan nomor urut arisan ini tidak sesuai menurut peneliti jika dikaitkan dengan firman-firman allah diatas terutama pada surah an-nahl ayat 90 dan penafsiran M. Quraish Quraish Shihab.

\section{Persentase Yang Diambil Oleh Ketua-Ketua Arisan}

Ibu Ayu selaku ketua arisan yang ada di Dusun Ntori Desa Wawonduru mengatakan bahwa perperiode arisan Ibu Ayu akan mendapatkan keuntungan kisaran Rp.20.000-30.000,- tergantung dengan harga barang, karna sering kali terjadi fluktuasi harga, sehingga keuntungan yang akan didapatkan oleh Ibu Ayu tergantung dengan harga barang yang ada, jika harga barang naik maka keuntungan yang akan didapatkan oleh ketua arisan hanyalah sedikit, namun ketika harga barang turun maka ketua arisan akan sedikit mendapatkan tambahan dari penurunan harga barang tersebut.

Dari penjelasan diatas peneliti dapat menarik kesimpulan bahwa ketua-ketua arisan yang ada di Desa Wawonduru mengambil keuntungan perperiode arisan kisaran Rp.20.000-100.000,- dan hal itu tergantung dengan fluktuasi harga barang yang ada dipasar. Keuntungan tersebut sebagai pengganti uang bensin para ketua-ketua arisan atas kerja kerasnya untuk mengumpulkan, membelikan barang hingga mengantarkan barang ke rumah pemenang undian.

a. Hukum Pengambilan Manfaat Qordh

Arisan adalah muamalah yang dibolehkan berdasarkan nash tentang iqrodh (mengutangi) yang mengandung unsur irfaq (membantu) pada muqtaridh. Muqtaridh pada arisan berutang harta untuk dimanfaatkan dalam jangka waktu tertentu kemudian dikembalikan tanpa penambahan atau pengurangan. ${ }^{22}$

Pengambilan manfaat qordh merupakan perbuatan yang dilarang Allah SWT, sebagai mana Hadis sebagai hujjah Ibnu Qudamah dalam mengharamkan pengambilan manfaat. Tentunya hal ini tidak bisa dianggap sepele karena sudah menyangkut ketetapan hukum Allah,

\footnotetext{
22 Muhammad Rohma Rozikin, Hukum Arisan Dalam Islam Kajian Fiqh Terhadap Praktik ROSCA (Ratating Savings And Credit Association), (Malang, UB press, 2018), 10.
} 
Menurut Ibnu Qudamah dalam buku Al-Mughni menjelaskan bahwasannya ada ketentuan-ketentuan yang berlaku didalam qordh:23

1) Qordh adalah sunnah bagi muqrid (yang memberikan pinjaman) dan mubah bagi muqtarid (yang meminjam) Dari Abu Darda' ,Aku meminjamkan dua dinar lalu dikembalikan kemudian meminjamkannya lagi, itu lebih aku sukai dari pada mensedekahkannya'. Oleh karena dalam pemberian pinjaman itu terdapat unsur mengeluarkan muslim yang lain dari kesulitan, memenuhi kebutuhannya, dan memberi pertolongan kepadanya, maka hukum Sunnah, seperti sedekah. Imam Ahmad berkata, orang yang diminta pinjaman lalu dia tidak memberi maka tidak berdosa. Hal itu karena memberi pinjaman adalah menyerupai sedekah Sunnah, sehingga tidak makruh bagi yang tidak memberinya. Imam Ahmad juga berkata, qordh bukan termasuk meminta-minta. Maksudnya bukan hal yang makruh, karena Nabi Muhammad SAW pernah melakukannya berdasarkan hadits Abu Rafi'. Seandainya itu makruh maka beliau pasti menghindarinya. Juga karena qordh adalah mengambil sesuatu dengan penggantinya, sehingga menyerupai orang yang membeli dengan utang yang menjadi tanggungannya. ${ }^{24}$ Ibnu Abu Musa Berkata, Aku tidak senang seandainya seseorang memberikan amanat sesuatu yang tidak sanggup ditunaikannya. Barang siapa ingin dipinjami, maka hendaknya mengetahui kondisi orang yang ingin meminjam kepadanya, dan tidak tertipu olehnya, kecuali yang dipinjam itu adalah sesuatu yang sepele dan tidak sulit baginya untuk mengembalikan yang serupa. Setelah itu imam Ahmad berkata. Apabila seseorang meminjam untuk orang lain, dan tidak memberitahu kondisi orang lain itu kepada orang yang memberi pinjaman, maka itu tidak baik, dia juga berkata, aku tidak menyukai seseorang meminjam untuk saudara-saudaranya dengan mengandalkan status sosialnya. Al Qadhi berkata, Maksudnya, apabila orang yang dimintakan pinjaman itu tidak dikenal sebagai orang yang menetapi janji, Karena hal itu dapat membahayakan harta orang yang memberi pinjaman. Namun, jika orang yang dimintakan pinjaman itu dikenal sebagai orang yang menepati janji, maka tidak makruh, karena hal tersebut merupakan upaya untuk membantu dan mengeluarkannya dari kesusahan.

23 Ibnu Qudamah, Al Mughni, Jilid 6, Penejemah Misbah Editor Abu Rania (Jakarta: Pustaka Azzam: 2009), 2-16

${ }^{24}$ Ibid, 13 
2) Qordh tidak sah kecuali dari orang yang diperbolehkan membelanjakan harta karena qordh adalah transaksi terhadap harta. Karena qordh Adalah transaksi terhadap Harta benda sehingga tidak sah kecuali dari orang yang diperbolehkan dengan leluasa membelanjakan hartanya, seperti jual-beli. Adapun hukumnya sama seperti hukum jual-beli dalam ijab qabul. Dalam transaksi qordh menggunakan kata salaf atau qordh, karena keduanya disebutkandalam syariat, dan juga setiap kata yang semakna dengan dua kata tersebut, seperti kalimat ,Aku serahkan ini menjadi milikmu', dengan syarat engkau mengembalikan penggantinya. Atau kalimat yang mengindikasikan kehendak melakukan Qordh. ${ }^{25}$ Seandainya seseorang mengatakan, aku serahkan ini menjadi milikmu tanpa menyebutkan keharusan mengembalikan penggantinya, dan tidak pula ada pula indikasi yang menunjukkan qordh, maka itu termasuk, seandainya peminjam dan yang meminjamkan itu berpendapat, maka yang dijadikan dasar adalah perkataan peminjam, karena bukti ada padanya, dan pengalihan kepemilikan tanpa ada pengganti adalah hibah.

3) Dalam qordh tidak berlaku khiyar (kebebasan memilih untuk melangsungkan dan membatalkan akad). Qordh tidak berlaku karena orang yang memberi pinjaman itu dalam keadaan menyadari bahwa keuntungan ada pihak lain, sehingga hal itu menyerupai hibah, dan yang meminjamkan boleh mengembalikannya kapan dia mau, dengan demikian, tidak membutuhkan adanya khiyar. Akad qordh kepemilikan ditetapkan jika harta itu sudah diserahkan dan diterima oleh yang meminjam. Ini adalah transaksi yang mengikat bagi yang meminjamkan, dan tidak mengikat bagi yang meminjam. Seandainya yang meminjamkan ingin menarik kembali hartanya, maka ia tida berhak. Orang yang memberi pinjaman telah menghilangkan kepemilikannya dengan menetapkan pengganti tanpa ada khiyar, sehingga dia tidak berhak menarik kembali harta miliknya itu, seperti barang yang telah dijual. Ini berbeda dengan barang yang diambil tanpa izin dan 'ariyah, karena kepemilikan terhadap keduanya tidak hilang, dan pemiliknya tidak berhak meminta barang yang semisal jika keduanya masih ada. Berbeda dengan masalah yang dibahas ini. Adapun orang yang meminjam harus mengembalikan harta yang dipinjamkannya kepada yang meminjamkannya apabila sifatnya tidak berubah, tidak berkurang,

${ }^{25} \mathrm{Ibid}, 14$ 
dan tidak terjadi cacat, dan karena barang tersebut tetap seperti apa yang menjadi hak orang yang meminjamkan, maka dia wajib menerimanya, seperti seandainya dia memberikannya kepada orang lain. Dimungkinkan orang yang meminjam tidak harus menerima apa yang tidak dicontohkan, karena qordh itu wajib dikembalikan sesuai nilai jualnya menurut salah satu dari dua pendapat. Apabila yang meminjamkan mengembalikan barang yang dipinjamkannya, maka dia belum mengembalikan apa yang menjadi kewajibannya, sehingga pemberi pinjaman pun tidak wajib menerimanya, seperti barang Pemberi pinjaman boleh meminta pengganti harta yang dipinjamkan seketika Pokok pembahasan inimerupakan faktor yang mengharuskan mengembalikan barang yang sama, sehingga seketika itu juga menjadikan pengembalian sebagai kewajiban, sama seperti pengerusakan barang. ${ }^{26}$ Seandainya seseorang memberi pinjaman dalam keadaan terpisah-pisah, kemudian dia meminta pengembalian sekaligus, maka diperbolehkan, karena seluruhnya diberikan pada saat yang sama. Hal ini serupa, jika dia menjualnya dengan beberapa kali transaksi secara kontan, kemudian meminta pembayaran sekaligus. Sesungguhnya waktu qordh tidak diakhirkan, ia dilakukan pada waktunya. Setiap utang yang telah jatu tempo tidak ditangguhkan dengan penangguhannya. Juga karena dua pihak yang bertransaksi itu memiliki hak untuk membatalkan atau melanjutkan, sehingga keduanyapun memiliki hak lebih didalamnya, serti khiyar majlis (hak membatalkan akad saat masih ditempat transaksi) dagangan.

4) Pemberi pinjaman boleh meminta pengganti harta yang dipinjamkan seketika Pokok pembahasan ini merupakan faktor yang mengharuskan mengembalikan barang yang sama, sehingga seketika itu juga menjadikan pengembalian sebagai kewajiban, sama seperti pengerusakan barang. Seandainya seseorang memberi pinjaman dalam keadaan terpisah-pisah, kemudian dia meminta pengembalian sekaligus, maka diperbolehkan, karena seluruhnya diberikan pada saat yang sama. Hal ini serupa, jika dia menjualnya dengan beberapa kali transaksi secara kontan, kemudia meminta pembayaran sekaligus. Sesungguhnya waktu qordh tidak diakhirkan, ia dilakukan pada waktunya. Setiap utang yang telah jatu tempo tidak ditangguhkan dengan penangguhannya. Juga karena dua pihak yang bertransaksi itu memiliki hak untuk membatalkan atau melanjutkan, sehingga

${ }^{26}$ Ibid, .15 
keduanyapun memiliki hak lebih didalamnya, serti khiyar majlis (hak membatalkan akad saat masih ditempat transaksi).

5) Setiap qordh yang disyaratkan adanya tambahan dari aslinya, maka hukumnya haram, hal ini tanpa diperselisihkan oleh para ulama. Bahwasanya Setiap qordh yang disyaratkan adanya tambahan dari aslinya, maka hukumnya haram. Hal ini tanpa diperselisihkan oleh para ulama'. Dari Ubai Bin Ka'ab, Ibnu Abbas dan Ibnu Mas'ud yang diambil dari buku Al-Mughni, bahwa mereka melarang memberi pinjaman dengan mengambil manfaat. Selain itu, pemberian pinjaman merupakan akad yang mengandung untuk tolong menolong dan mendekatkan diri kepada Allah. Apabila disyaratkan adanya tambahan, maka akan mengeluarkannya dari tujuan semula.

6) Apabila seseorang memberi pinjaman tanpa syarat, lalu orang yang meminjam membayarnya dengan yang lebih baik dari kadar atau sifatnya, atau rendah, dengan kerelaan masing-masing, maka itu diperbolehkan. Begitu juga diperbolehkan jika menetapkan agar piutangnya dibayar melalui wesel (Bill of Exchange) atau dibayar ditempat lain. Apabila pengutang membayar dengan yang lebih baik atau menambahkan sesudah pelunasan tanpa kesepakatan, maka ada dua riwayat. Riwayat pertama dari Ubai Bin Ka'ab, Ibnu Abbas dan Ibnu Umar bahwa dia harus mengambil yang sepadan dengan yang dipinjamkannya dan tidak mengambil kelebihannya, karena jika dia mengambil kelebihannya, maka merupakan pinjaman dengan mengambil kelebihan tersebut. Nabi Muhammad SAW pernah meminjam anak unta dari seseorang, lalu beliau mengembalikannya lebih baik. Hal ini karena beliau tidak menjadikan tambahan itu sebagai pengganti dalam pinjamannya, bukan sebagai sarana untuk memperoleh pinjaman, dan bukan pula untuk pelunasannya, sehingga tambahan tersebut halal seperti halnya jika tidak ada pinjaman. ${ }^{27}$ Berdasarkan penjelasan konsep Ibnu Qudamah tentang pengambilan manfaat qordh, maka ketidak seimbangan yang ditimbulkan dari pengambilan manfaat qordh. Qordh pada dasarnya sebagai sarana untuk tolong menolong dalam bentuk utang piutang. Sehingga apabila terdapat kelebihan atau ketidak seimbangan maka akan dapat merusak akad dan menzalimi anggota lainnya. Pada dasarnya, Allah sangat menganjurkan hamba-Nya untuk saling tolong menolong dalam kebaikan, salah satu bentuk wujudnya yaitu dengan adanya utang

27 Ibid, .15 . 
piutang. Selain memperkuat tali persaudaraan, kegiatan ini juga dapat meringankan beban orang yang sedang mengalami kesulitan, sehingga Allah sangat menganjurkan untuk melakukan utang piutang. ${ }^{28}$ Diriwayatkan dari Ubai Bin Ka'ab, Ibnu Abbas dan Ibnu Mas'ud bahwa mereka melarang memberi pinjaman dengan mengambil manfaat. Selain itu, pemberian pinjaman merupakan akad yang mengandung untuk tolong menolong dan mendekatkan diri kepada Allah. Apabila disyaratkan adanya tambahan, maka akan mengeluarkannya dari tujuan semula. Tidak ada perbedaan antara tambahan dari segi kadar sifat. Seperti seseorang meminjamkan sesuatu yang pecah untuk diganti dengan yang baik, atau uang perak untuk diganti dengan yang lebih baik. Jika peminjam mensyaratkan agar barang diserahkan ditempat lain, padahal membawanya ketempat tersebut membutuhkan biaya, maka itu tidak diperbolehkan. jika tidak membutuhkan biaya untuk membawanya maka diperboleh.

\section{KESIMPULAN}

Praktik arisan barang yang dilakukan oleh masyarakat Desa Wawonduru menggunakan akad lisan dalam membuat kesepakatan, setiap ketua arisan mengambil persentase persekali periode arisan, anggota arisan memiliki kebiasaan untuk meminta ganti nomor undian, dan terdapat unsur penipuan terhadap kualitas barang arisan.

\section{DAFTAR PUSTAKA}

Amalia,U. Keadilan Distributif Dalam Ekonomi Islam, (Jakarta, Raja Grafindo Persada, 2009),115-116.

Erwandi, T.(2019). Praktik Arisan Barang Dalam Kajian Hukum ekonomi Syariah (Studi di Desa Sebangau Permai Kecamatan Sebangau Kuala kabupaten Pulang Pisau), repository-iain-palangkaraya.ic,id.

Hidayat.T.(2018).Hukum Pengambilan Manfaat Qordh Terhadap Praktik Arisan Uang Perspektif Ibnu Qudamah.Repositori Uinsu.Ac.Id.

Hidayat.T.(2018).Hukum Pengambilan Manfaat Qordh Terhadap Praktik Arisan Uang Perspektif Ibnu Qudamah.Repositori Uinsu.Ac.Id.

Irwan, Indraddin. (2016) Strategi dan Perubahan Sosial. Yogyakarta: Deepublish. Muslimah,E.(2019).Sistem Arisan Perabot Rumah Tangga Perspektif Etika Bisnis Islam di Desaraman Aji Paomacan Kecamatan Sukamaju Kabupaten Luwu Utara Lampung Timur' ', repository-iain-metro.ac.id.

28Taufiq Hidayat, Hukum Pengambilan Manfaat Qordh Terhadap Praktik Arisan Uang Perspektif Ibnu Qudamah, Http:/ /Repository.Uinsu.Ac.Id. Diambil Pada Tanggal 22 Juni 2021,Pukul 20:12 Wita. 
Olana,A.(2019).Praktik Jual Beli Dengan Sistim Arisan (Study Kasus Akun Facebook Rica Nadef),.repository.iain-metro.ac.id.

Qudamah.I,Al-Mughni.(2009).Jilid 6 Penerjemah Misbah Editor Abu Rania, Jakarta: Pustaka Azzam.

Roesma , Mulya, (2013). Kocok, Uncuk-The, Untolt Stories Of Arisan Ladies And Sosiatites. Jakarta: Pt Gramedia.

Romdlon S.A, Konsep Keadilan Menurut Al-QureeAn Dan Para Filosof, Jurnal Dialogia, Ponorogo: STAIN Ponorogo, No.2/ Vol. 10/ 2012, 186.

Rozikin, M.R. (2018). Hukum Arisan Dalam Islam Kajian Figh Terhadap Praktik Rosca (Rotating Savings And Credit Asosiation). Malang: Ub Press.

Soemitro, A. (2019). Hukum Ekonomi Syariah dan Figh Muamalah di Lembaga Keuangan dan Bisnis. Jakarta: Prenadamedia Groub.

Triwulan.T.T, Pengantar Ilmu Hukum, (Jakarta: Prestasi Pustaka, 2006), 227.

Uis Amalia, Keadilan Distributif Dalam Ekonomi Islam, (Jakarta, Raja Grafindo Persada, 2009),115-116. 